Levitsky A. P., Khodakov I. V., Pupin T. I., Markov A. V., Selivanskaya I. A. Effect of fat diet on essential fatty acid metabolism of neutral lipids in rat blood serum. Journal of Education, Health and Sport. 2021;11(04): 113-121. eISSN 2391-8306. DOI http://dx.doi.org/10.12775/JEHS.2021.11.04.012

https://apcz.umk.pl/czasopisma/index.php/JEHS/article/view/JEHS.2021.11.04.012

https://zenodo.org/record/4768511

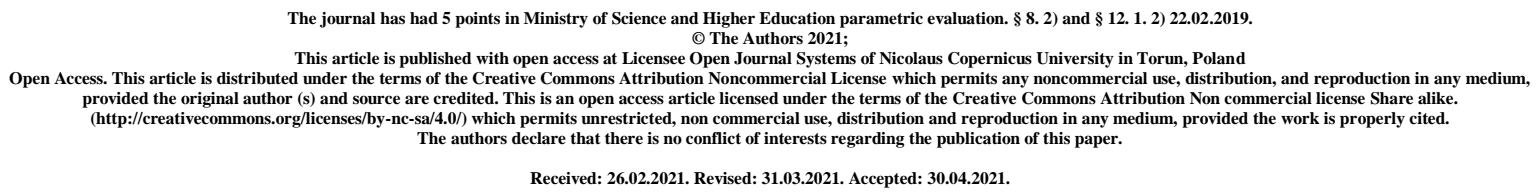

UDK $616.314+664.315$

\title{
EFFECT OF FAT DIET ON ESSENTIAL FATTY ACID METABOLISM OF NEUTRAL LIPIDS IN RAT BLOOD SERUM
}

\author{
A. P. Levitsky¹, I. V. Khodakov², T. I. Pupin ${ }^{3}$, A. V. Markov ${ }^{3}$, I. A. Selivanskaya ${ }^{4}$
}

1Odessa National Academy of Food Technologies

${ }^{2} \mathrm{SE}$ «The Institute of Stomatology and Maxillo-Facial Surgery of the National Academy of Medical Science of Ukraine», Odessa

${ }^{3}$ Lviv National Medical University named after Danylo Galytskij

${ }^{4}$ Odessa National Medical University

\begin{abstract}
Aim. To determine the effect of dietary fats on the content and metabolism of polyunsaturated fatty acids (PUFA) in the fraction of neutral lipids blood serum.

Methods. The effect of sunflower, high oleic sunflower (HOSO) and palm oils was studied when feeding rats with diets with $5 \%$ fat for 30 days. Rats fed a fat-free diet (FFD) served as a control. The fatty acid composition of neutral blood serum lipids was determined by gas chromatography. The "activity" of fatty acid biosynthesis enzymes: elongase and desaturases was calculated from the ratio of the content of fatty acids.

Results. A high content of PUFA was found in rats treated with FFD. Feeding rats with a diet with $5 \%$ sunflower oil increased the total content of PUFAs with a slight decrease in the level of $\omega-3$ PUFAs. Feeding rats with diets containing $5 \%$ palm oil or HOSO did not affect the total content of PUFA, but increased the content of $\omega-3$ PUFA. A very high
\end{abstract}


"activity" of stearyl-CoA desaturase was found in rats fed FFD and fat diets. The consumption of HOSO inhibits the formation of arachidonic acid, while the consumption of palm oil enhances it.

Conclusions. A high level of PUFA in neutral lipids in the blood serum of rats may indicate the presence of endogenous sources of PUFA. The optimal (for rats) consumption of dietary fats has a small effect on the content and metabolism of PUFA, with the exception of sunflower oil, the consumption of which significantly increases the $\omega-6 / \omega-3$ PUFA ratio.

Key words: polyunsaturated fatty acids; fat nutrition; biosynthesis of fatty acids.

\section{Introduction}

The fraction of neutral blood serum lipids is represented by triglycerides and cholesterol esters. This is the largest part of serum lipids (80-85 \% of all lipids). And although the content of polyunsaturated fatty acids (PUFA) in this fraction is lower than in the fraction of phospholipids [1], nevertheless, most of the PUFA is found in the fraction of neutral lipids. As you know, the animal organism is able to synthesize fatty acids from carbohydrates, amino acids, ethyl alcohol (Fig. 1). In this case, palmitic acid $\left(\mathrm{C}_{16: 0}\right)$ is formed, which further, under the influence of the elongase enzyme, turns into stearic acid $\left(\mathrm{C}_{18: 0}\right)$, and the latter, under the influence of the stearyl-CoA desaturase enzyme, turns into oleic acid $\left(\mathrm{C}_{18: 1}\right)$, the main energetic substance of an animal organism [2].

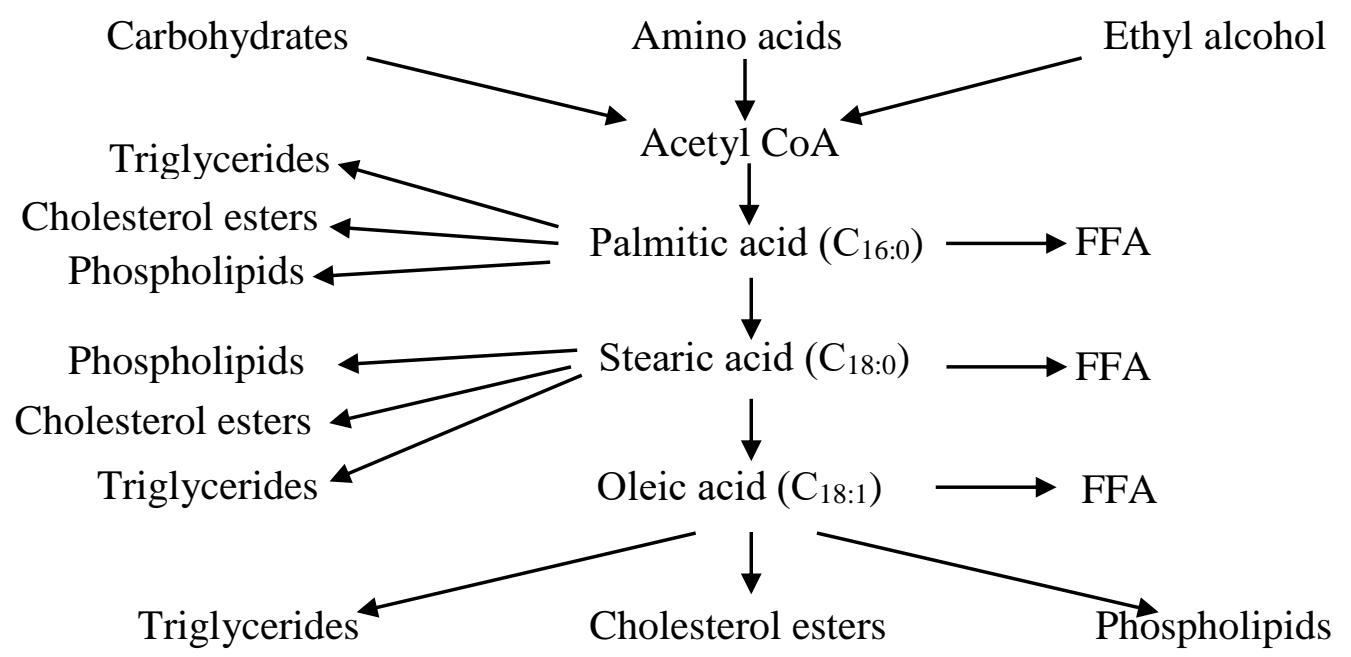

Fig. 1. Scheme of biosynthesis and transformations of fatty acids in an animal organism

Oleic acid is oxidized best of all fatty acids in mitochondria, with the formation of ATP [3]. Oleic acid is the main component of subcutaneous fat [4]. It was found that oleic 
acid in an animal organism cannot be converted into PUFA [5]. Therefore, dietary fats are a source of PUFA for an animal organism. Moreover, absolutely irreplaceable (essential) is only one - linoleic $\left(\mathrm{C}_{18: 2}, \omega-6\right)$. All other PUFAs can be synthesized from it (Fig. 2). True, the process of conversion of linoleic acid into $\omega-3 \alpha$-linolenic acid in an animal organism is strongly inhibited [6]. Therefore, the animal organism needs additional intake of $\alpha$-linolenic and other polyunsaturated fatty acids of the $\omega-3$ series with food [7].

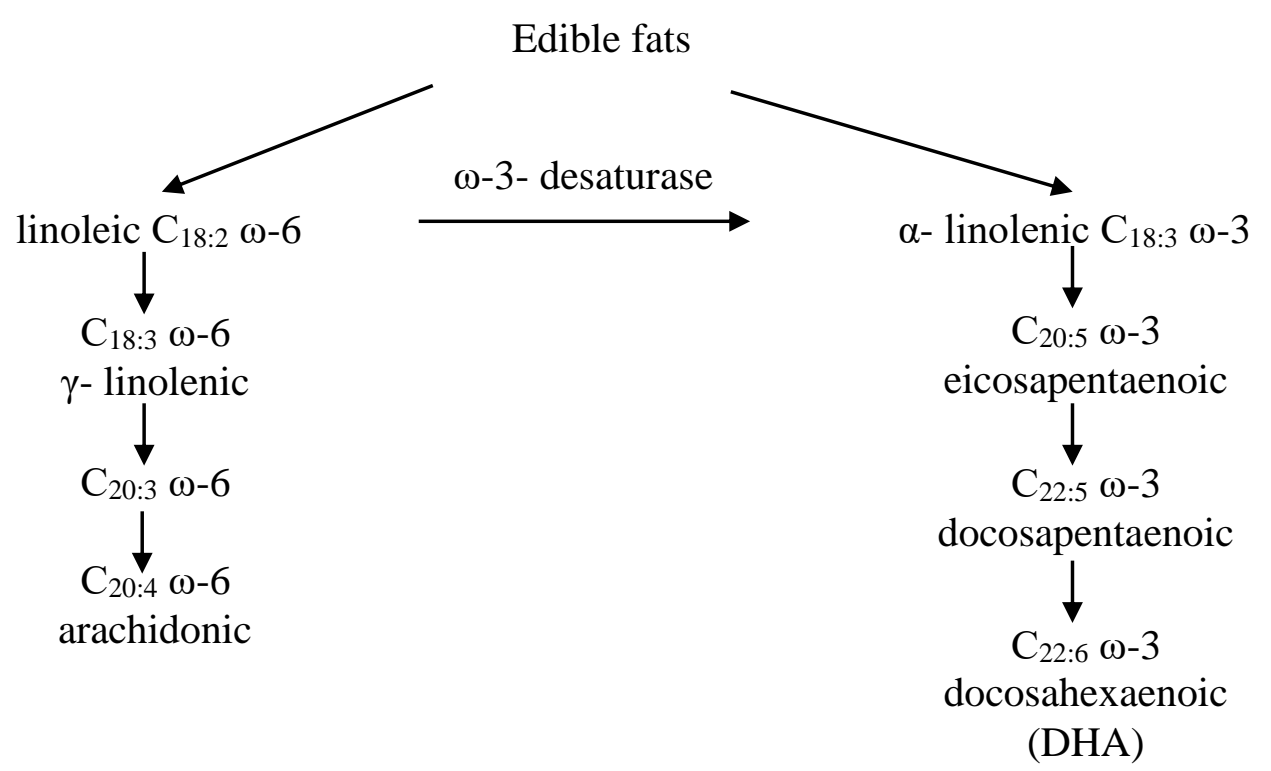

Fig. 2. Scheme of the conversion of $\mathrm{C}_{18}$ PUFA into long-chain PUFA $\left(\mathrm{C}_{20}\right.$ и $\left.\mathrm{C}_{22}\right)$

$\omega$-3 PUFA (eicosapentaenoic acid) is necessary for the formation of physiologically active substances, eicosanoids (prostaglandins, leukotrienes, thromboxanes), which have antiinflammatory, cytoprotective properties [8]. Physiologically active compounds (protectins, resolvins, etc.) are also formed from docosahexaenoic acid (DHA), which stop the inflammatory reaction and have a reparative effect on tissues and organs [9].

We have previously shown that high-fat nutrition significantly inhibits the endogenous biosynthesis of $\omega$-3 PUFA from $\alpha$-linolenic acid [10].

Considering that the diet of a modern person contains a large amount of fat (up to 30 $\%)$, containing very little PUFA, the problem of enriching food with essential fatty acids becomes urgent.

The aim of this study was to determine the effect on the level of PUFA and the processes of their biosynthesis in neutral lipids of the blood serum of rats receiving FFD and 
fat diets with an optimal (for rats) level of dietary fats, with different contents of linoleic acid, with almost complete absence of all other PUFA.

\section{Material and research methods}

The following edible fats were used in the work: unrefined frozen pressed sunflower oil (manufactured by "Smak Sontsya") V.V. Marchenko, Ukraine); high oleic sunflower oil (HOSO) "Olivka" (SPA "Odessa Biotechnology", Ukraine); palm oil "Dukees RBD" (Malaysia).

The fatty acid composition of these vegetable oils was determined by gas chromatography [11].

Biological experiments were carried out on white Wistar rats (males, 5 months old, body weight 225-235 g), distributed into 4 groups of 6 animals each: $1^{\text {st }}$ (control) received a fat-free diet (FFD), the composition of which is presented in table 1; The second received a diet with $5 \%$ sunflower oil; $3^{\text {rd }}$ received a diet with $5 \%$ HOSO and $4^{\text {th }}$ received a diet with 5 $\%$ palm oil.

Table 1. Composition of diets for rats (\%) [12]

\begin{tabular}{|l|c|c|}
\hline \multicolumn{1}{|c|}{ Components } & $\begin{array}{c}\text { Fat free diet } \\
\text { (FFD) }\end{array}$ & Fat diets \\
\hline Corn starch & 65 & 60 \\
\hline Fat-free soybean meal & 20 & 20 \\
\hline Ovalbumin & 6 & 6 \\
\hline Sugar & 4 & 4 \\
\hline $\begin{array}{l}\text { Mineral mixture (macro- and } \\
\text { microelements) }\end{array}$ & 4 & 4 \\
\hline Vitamin Blend & 1 & 1 \\
\hline Vegetable oil & 0 & 5 \\
\hline
\end{tabular}

Feeding lasted 30 days, and after euthanasia of the animals under thiopental anesthesia (20 mg/kg), blood serum was obtained from the heart by total bloodletting. The blood serum of rats of each group was pooled and used for lipid extraction according to Dole [13], isolating three fractions: neutral lipids (triglycerides + cholesterol esters), phospholipids, and free fatty acids (FFA) [1]. The fatty acid composition of each fraction was determined in triplicate by gas chromatography [11] and the average values were obtained, which for the neutral lipid fraction are presented in Table 2.

The "activity" of enzymes of the biosynthesis of fatty acids was determined indirectly by the ratio of the levels of fatty acids (process products) and fatty acids (initial substrates). Thus, the "activity" of elongase was calculated from the ratio of the content of stearic $\left(\mathrm{C}_{18: 0}\right)$ and palmitic $\left(\mathrm{C}_{16: 0}\right)$ acids. The "activity" of stearyl-CoA desaturase was calculated from the 
ratio of the content of oleic $\left(\mathrm{C}_{18: 1}\right)$ and stearic acids. The "activity" of $\omega$-3-desaturase was calculated from the ratio of the total content of all $\omega-3$ PUFA (linolenic, eicosapentaenoic, docosapentaenoic and docosahexaenoic) and the content of linoleic acid $\left(\mathrm{C}_{18: 2} \omega-6\right)$.

The intensity of the process of biosynthesis of arachidonic acid (ISAA) was calculated from the ratio of the content of arachidonic $\left(\mathrm{C}_{20: 4}\right)$ and linoleic acids.

The intensity of the synthesis of docosahexaenoic acid (ISDHA) was calculated from the ratio of the content of DHA and $\alpha$-linolenic acid $\left(\mathrm{C}_{18: 3} \omega-3\right)$.

\section{Results and discussion}

Table 2 shows the results of determining the fatty acid composition of the used vegetable oils. It can be seen that all three fats lack long-chain PUFA $\left(\mathrm{C}_{20}\right.$ and $\left.\mathrm{C}_{22}\right)$. Ordinary sunflower oil contains a lot of linoleic acid (57\%), HOSO - a lot of oleic acid (84\%) and palm oil contains a lot of palmitic acid (almost $46 \%$ ). All three oils contain only trace amounts of $\alpha$-linolenic acid (0.03-0.08\%).

Table 2. Fatty acid composition of edible fats

\begin{tabular}{|l|c|c|c|c|}
\hline \multicolumn{1}{|c|}{ Fatty acid } & $\begin{array}{c}\text { Short } \\
\text { formula }\end{array}$ & Sunflower oil & $\begin{array}{c}\text { High oleic } \\
\text { sunflower oil }\end{array}$ & Palm oil \\
\hline Lauric & $\mathrm{C}_{12: 0}$ & 0 & 0,04 & 0,32 \\
\hline Myristic & $\mathrm{C}_{14: 0}$ & 0,12 & 0,06 & 0,98 \\
\hline Palmitic & $\mathrm{C}_{16: 0}$ & 6,63 & 4,15 & 45,72 \\
\hline Palmitooleic & $\mathrm{C}_{16: 1}$ & 0,12 & 0,13 & 0,08 \\
\hline Stearic & $\mathrm{C}_{18: 0}$ & 2,86 & 2,75 & 4,70 \\
\hline Oleic & $\mathrm{C}_{18: 1}$ & 30,29 & 84,55 & 38,58 \\
\hline Linoleic & $\mathrm{C}_{18: 2} \omega-6$ & 57,12 & 6,16 & 8,20 \\
\hline$\alpha$-linolenic & $\mathrm{C}_{18: 3} \omega-3$ & 0,03 & 0,08 & 0,06 \\
\hline Arachidonic & $\mathrm{C}_{20: 4} \omega-6$ & 0 & 0 & 0 \\
\hline Eicosapentaenoic & $\mathrm{C}_{20: 5} \omega-3$ & 0 & 0 & 0 \\
\hline Docosapentaenoic & $\mathrm{C}_{22: 5} \omega-3$ & 0 & 0 & 0 \\
\hline Docosahexaenoic & $\mathrm{C}_{22: 6} \omega-3$ & 0 & 0 & 0 \\
\hline
\end{tabular}

In fig. 3 shows the results of determining the content of PUFA in three fractions of rat blood serum lipids. It can be seen that the total content of PUFA in the composition of neutral blood serum lipids is significantly lower than in the fraction of phospholipids. In rats fed a fat diet with $5 \%$ sunflower oil, the content of PUFA sharply increases (due to $\omega$-6 PUFA) in all fractions and especially strongly (2 times) in the neutral lipid fraction. The other two oils (HOSO and palm), which were low in linoleic acid, had a significantly lesser effect on PUFA levels. 


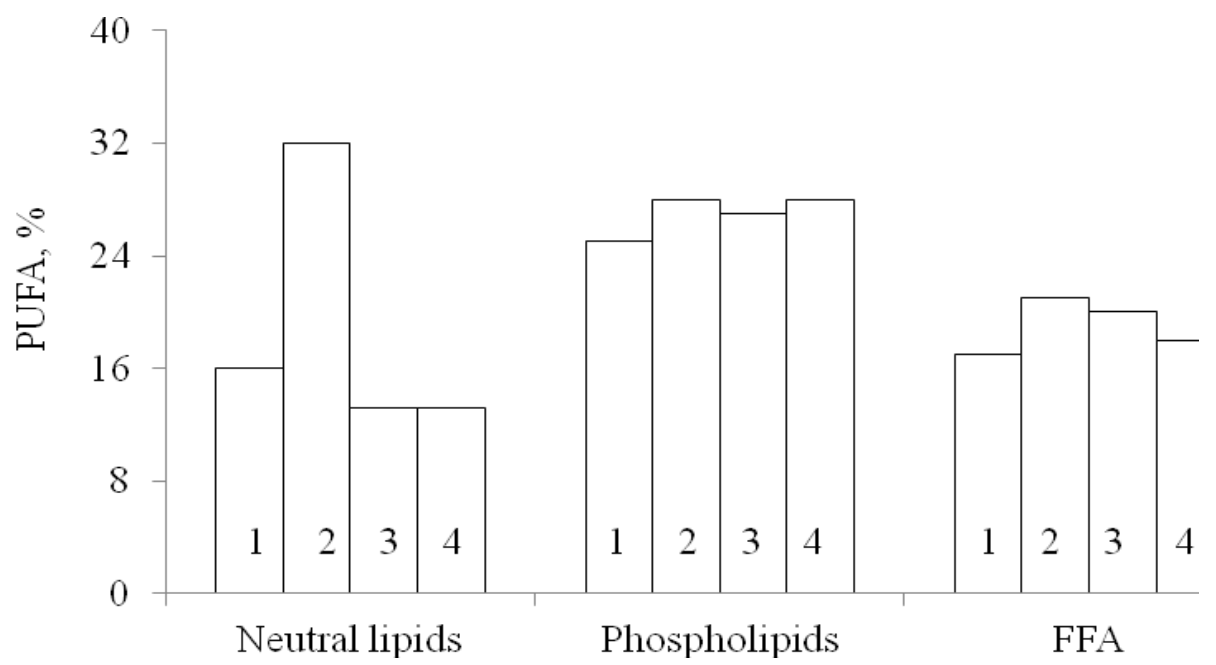

Fig. 3. Influence of fat diet on the content of PUFA in the lipid fractions of blood serum of rats

(1 - FFD; 2 - sunflower oil, $5 \% ; 3$ - HOSO, $5 \%$; 4 - palm oil, $5 \%$ )

Table 3 shows the results of determining the fatty acid composition of neutral lipids in the blood serum of rats receiving FFD and fat diets. The most amazing thing is that in rats fed a fat-free diet, a complete set of all fatty acids, including $\omega-3$ PUFA, is determined. As we have already indicated, during the endogenous biosynthesis of fatty acids in the animal organism, only palmitic, stearic and oleic acids are formed. When they are converted in the body, PUFA are not formed. Therefore, it is assumed that PUFA in an animal organism may be of endogenous origin due to their reutilization from dying cells, as well as due to the formation of endogenous microbiota. The latter is observed in ruminants. It is possible that it can also occur in the body of rats.

Table 3. Effect of fatty diet on fatty acid composition of neutral lipids (triglycerides + cholesterol esters) in rat blood serum

\begin{tabular}{|l|c|c|c|c|}
\hline \multicolumn{1}{|c|}{ Fatty acid } & FFD & $\begin{array}{c}\text { Sunflower oil } \\
5 \%\end{array}$ & HOSO 5\% & $\begin{array}{c}\text { Palm oil } \\
5 \%\end{array}$ \\
\hline Lauric & 0 & 0 & 0 & 0,11 \\
\hline Myristic & 1,29 & 1,05 & 1,24 & 1,27 \\
\hline Palmitic & 31,43 & 21,62 & 20,66 & 25,27 \\
\hline Palmitooleic & 11,19 & 6,08 & 4,61 & 5,69 \\
\hline Stearic & 2,65 & 1,69 & 1,31 & 2,23 \\
\hline Oleic & 39,85 & 33,37 & 54,10 & 44,86 \\
\hline Linoleic & 6,23 & 27,29 & 11,27 & 14,27 \\
\hline$\alpha$-linolenic & 0,18 & 0,23 & 0,31 & 0,22 \\
\hline Arachidonic & 2,27 & 2,69 & 1,32 & 1,38 \\
\hline Eicosapentaenoic & 0,10 & 0,01 & 0,02 & 0,06 \\
\hline Docosapentaenoic & 0,13 & 0,09 & 0,12 & 0,16 \\
\hline Docosahexaenoic & 0,23 & 0,13 & 0,27 & 0,22 \\
\hline
\end{tabular}


Table 4 shows the results of determining the composition and ratio of PUFA in neutral blood serum lipids. It can be seen that the highest content of $\omega-3$ PUFA is observed in rats treated with HOSO, and the lowest in rats treated with ordinary sunflower oil. Therefore, the ratio of $\omega-6 / \omega-3$ PUFA in this case is the highest (almost 47 ), while in rats treated with $\mathrm{HOSO}$, it is equal to 13 .

Table 4. Influence of fat nutrition on the distribution of PUFA in the fraction of neutral lipids in the blood serum of rats

\begin{tabular}{|l|c|c|c|c|}
\hline \multicolumn{1}{|c|}{ Indicators } & FFD & $\begin{array}{c}\text { Sunflower oil } \\
5 \%\end{array}$ & HOSO 5\% & $\begin{array}{c}\text { Palm oil } \\
5 \%\end{array}$ \\
\hline PUFA content, $\%$ & 16,0 & 32,6 & 15,6 & 14,7 \\
\hline Content of $\omega$-6 PUFA, $\%$ & 15,2 & 31,9 & 14,5 & 13,8 \\
\hline Content of $\omega-3$ PUFA, $\%$ & 0,78 & 0,68 & 1,11 & 0,91 \\
\hline The ratio $\omega-6 / \omega-3$ PUFA & 19,5 & 46,9 & 13,1 & 15,1 \\
\hline $\begin{array}{l}\text { The ratio } \mathrm{C}_{20}+\mathrm{C}_{22} / \mathrm{C}_{18} \\
\text { PUFA }\end{array}$ & 0,21 & 0,18 & 0,18 & 0,27 \\
\hline Content $\mathrm{C}_{16: 0}+\mathrm{C}_{16: 1}$ & 36,9 & 26,3 & 27,4 & 34,2 \\
\hline
\end{tabular}

The proportion of long-chain PUFA was highest in rats fed with palm oil, although it does not. The proportion of palmitic acid $\left(\mathrm{C}_{16: 0}+\mathrm{C}_{16: 1}\right)$ was the highest in rats fed with FFD and a diet with $5 \%$ palm oil.

Table 5 shows the results of determining the "activity" of some enzymes of the biosynthesis of fatty acids. It can be seen that the "activity" of elongase, which converts palmitic acid into stearic acid, is very low, apparently due to the very high (200-250 times) activity of stearyl-CoA desaturase, which rapidly converts stearic acid into oleic acid.

Table 5. Influence of fat nutrition on the "activity" of enzymes of PUFA biosynthesis (in terms of fatty acid composition of neutral lipids in rat blood serum)

\begin{tabular}{|c|c|c|c|c|}
\hline Indicators & FFD & $\begin{array}{c}\text { Sunflower oil } \\
5 \%\end{array}$ & HOSO $5 \%$ & $\begin{array}{l}\text { Palm oil } \\
5 \%\end{array}$ \\
\hline «Elongaza» $\left(\mathrm{C}_{18: 0} / \mathrm{C}_{16: 0}\right)$ & 0,075 & 0,081 & 0,083 & 0,085 \\
\hline $\begin{array}{l}\text { «Stearyl-CoA desaturase» } \\
\left(\mathrm{C}_{18: 1} / \mathrm{C}_{18: 0}\right)\end{array}$ & 19,3 & 20,4 & 28,1 & 19,0 \\
\hline $\begin{array}{l}\ll \omega-3-\text { desaturase } \\
(\Sigma \omega-3 \text { PUFA/C } 18: 2)\end{array}$ & 0,061 & 0,025 & 0,087 & 0,082 \\
\hline $\begin{array}{l}\text { The intensity of the } \\
\text { synthesis of arachidonic } \\
\text { acid }\left(\mathrm{C}_{20: 4} / \mathrm{C}_{18: 2}\right)\end{array}$ & 0,184 & 0,171 & 0,138 & 0,239 \\
\hline $\begin{array}{l}\text { The intensity of the } \\
\text { synthesis of } \\
\text { docosahexaenoic acid } \\
\left(\mathrm{C}_{22: 6} / \mathrm{C}_{18: 3}\right)\end{array}$ & 0,611 & 0,577 & 0,531 & 0,454 \\
\hline
\end{tabular}


The very low indices of the "activity" of $\omega$-3-desaturase that we established indicate that the endogenous synthesis of $\omega-3$ PUFA from $\omega-6$ PUFA in the animal body is very limited and is strongly inhibited by sunflower oil even with a relatively low consumption of the latter.

Unlike sunflower oil, high oleic sunflower and palm oils do not inhibit the "activity" of $\omega-3$ desaturase. Moreover, palm oil activates the synthesis of arachidonic acid.

\section{Conclusions}

1. In rats that received a fat-free diet, PUFA of both $\omega-6$ and $\omega-3$ series are formed. Supposed sources of endogenous PUFA may be the re-utilization of own PUFA and endogenous microbiota.

2. Consumption of HOSO and palm oil increases the formation of $\omega-3$ PUFA, while decreasing the $\omega-6 / \omega-3$ ratio.

3. In rats, a very high "activity" of stearyl-CoA desaturase and a very low "activity" of $\omega-3$ desaturase were noted.

4. High oleic sunflower oil inhibits the synthesis of arachidonic acid.

\section{References}

1. Levitsky AP, Khodakov IV, Tkachuk VV. The comparative estimation of influence of higholeic sunflower and palm oils consumption on the fatty acids content of rat liver lipids. Journal of Education, Health and Sport. 2017;7(2):305-318. DOI http://dx.doi.org/10.5281/zenodo.376811

2. Tvrzická, E., Žák, A., Vecka, M. [and others]. Fatty Acids in Human Metabolism. Physiology and maintenance. 2009; II: 274-302.

3. Titov VN. Oleic fatty acid, oleic, linolic, linolenic and low-density lipoproteins. Clinical laboratory diagnosis. 2006;6:3-16. (in Russian)

4. Titov VN, Lisitsyn DM, Razumovskiy SD. Methodic questions and diagnostic values of the determination of lipid peroxide oxidation in low density lipoproteins. Oleic fatty acid as biological antioxidant (review of literature). Clinical laboratory diagnosis. 2005;4:310. (in Russian)

5. Titov VN, Lisitsyn DM. Fat acids. Physical chemistry, biology and medicine. Tver, Triada, 2006:672. (in Russian)

6. Plourde M, Cunnane SC. Extremely limited synthesis of long chain polyunsaturates in adults: implications for their dietary essentiality and use as supplements. Appl Physiol Nutr Metab. 2007;32(4):619-34. doi: 10.1139/H07-034. 
7. Levitsky AP, Khodakov IV, Lapinskaia AP [and others]. Vitamin F (essential polyunsaturated fatty acids $\omega-6$ and $\omega-3$ PUFA. Odessa, FLP Tashchenko S. Iu., 2020:65. (in Russian)

8. Piper K, Garelnabi M. Eicosanoids: Atherosclerosis and cardiometabolic health. J Clin Transl Endocrinol. 2020;19:100216. doi: 10.1016/j.jcte.2020.100216.

9. Souza PR, Marques RM, Gomez EA [and others]. Enriched Marine Oil Supplements Increase Peripheral Blood Specialized Pro-Resolving Mediators Concentrations and Reprogram Host Immune Responses: A Randomized Double-Blind Placebo-Controlled Study. Circ Res. 2020;126(1):75-90. doi: 10.1161/CIRCRESAHA.119.315506

10. Levitsky AP, Khodakov IV, Levchenko EM. Influence of high fat diets with different composition of fatty acids on the content of essential fatty acids in liver lipids.Journal of Education, Health and Sport.2015;5(12):598-607. DOI http://dx.doi.org/10.5281/zenodo.44266

11. Levitsky AP, Makarenko OA, Khodakov IV. Methods to investigate fats and oils. Odessa, KP OGT, 2015: 32. (in Russian)

12. Levitsky A. P., Makarenko O. A., Demyanenko S. A. Methods of experimental dentistry. Simferopol, Tarpan, 2018: 78. (in Russian)

13. Keyts M. Metods of lipidology. Recciving, analise and identification of lipids. M., Mir, 1975:334. (in Russian)

14. Levitsky A. P., Egorov B. V., Gozhenko A. I., Badiuk N.S., Selivanskaya I. A., Lapinskaya A. P. Influence of high-fat nutrition with different fat-acid composition of fats on lipid peroxidation processes in rat's organs and tissues / PharmacologyOnLine; Archives 2021 vol.1 $37-46$ https://pharmacologyonline.silae.it/files/archives/2021/vol1/PhOL_2021_1_A006_Levitsky.p df 